\title{
Malaria Vectors and Vector Surveillance in Limpopo Province (South Africa): 1927 to 2018
}

\author{
Leo Braack ${ }^{1, *}$, Riana Bornman ${ }^{1}$, Taneshka Kruger ${ }^{1}$, Yael Dahan-Moss ${ }^{2,3}$, Allison Gilbert ${ }^{2,3}$, \\ Maria Kaiser ${ }^{2,3}$, Shüné V. Oliver ${ }^{2,3}{ }^{(0)}$, Anthony J. Cornel ${ }^{1,4}$, Yoosook Lee ${ }^{4}$, Douglas E. Norris ${ }^{5}$,

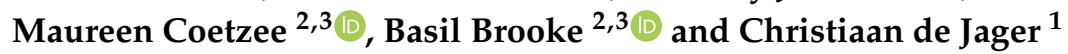

1 University of Pretoria Institute for Sustainable Malaria Control, School of Health Systems and Public Health, Faculty of Health Sciences, University of Pretoria, Pretoria 0028, South Africa; riana.bornman@up.ac.za (R.B.); taneshka.kruger@up.ac.za (T.K.); ajcornel@ucanr.edu (A.J.C.); tiaan.dejager@up.ac.za (C.d.J.)

2 Vector Control Reference Laboratory, Centre for Emerging, Zoonotic \& Parasitic Diseases, National Institute for Communicable Diseases, Johannesburg2001, South Africa; Yaeld@nicd.ac.za (Y.D.-M.); allisong@nicd.ac.za (A.G.); mariak@nicd.ac.za (M.K.); shuneo@nicd.ac.za (S.V.O.); maureen.coetzee@wits.ac.za (M.C.); basilb@nicd.ac.za (B.B.)

3 Wits Research Institute for Malaria, School of Pathology, Faculty of Health Sciences, University of the Witwatersrand, Johannesburg 2001, South Africa

4 Department of Entomology \& Nematology, University of California, Davis, CA 95616, USA; yoosook.lee@gmail.com

5 The W Harry Feinstone Department of Molecular Microbiology and Immunology, Johns Hopkins Malaria Research Institute, Johns Hopkins Bloomberg School of Public Health, Baltimore, MD 21205, USA; douglas.norris@jhu.edu

* Correspondence: leo.braack@up.ac.za

Received: 10 May 2020; Accepted: 6 June 2020; Published: 9 June 2020

\begin{abstract}
Despite the annual implementation of a robust and extensive indoor residual spraying programme against malaria vectors in Limpopo Province (South Africa), significant transmission continues and is a serious impediment to South Africa's malaria elimination objectives. In order to gain a better understanding regarding possible causes of this residual malaria, we conducted a literature review of the historical species composition and abundance of malaria vector mosquitoes in the Limpopo River Valley region of the Vhembe District, northern Limpopo Province, the region with the highest remaining annual malaria cases in South Africa. In addition, mosquito surveys were carried out in the same region between October 2017 and October 2018. A total of 2225 adult mosquitoes were collected using $\mathrm{CO}_{2}$-baited tent and light traps, human landing catches and cow-baited traps. Of the 1443 Anopheles collected, 516 were members of the An. gambiae complex and 511 An. funestus group. In the malaria endemic rural areas outside the Kruger National Park, one specimen each of An. gambiae s.s. and An. funestus and only three of An. arabiensis were collected. The latter species was abundant at a remote hot spring in the neighboring Kruger National Park. Eighteen other species of Anopheles were collected. Our survey results support the historical findings that An. arabiensis, the species widely held to be the prime malaria vector in South Africa, is a rare species in the malaria endemic Limpopo River Valley. The implications of the mosquito surveys for malaria transmission, elimination and vector control in northern Limpopo Province and neighboring regions are discussed.
\end{abstract}

Keywords: malaria; Anopheles; Limpopo Province; South Africa; vector surveillance

\section{Introduction}

The more northern regions of the Republic of South Africa have historically suffered heavily from the impact of malaria, reflected in both popular and scientific accounts [1-4]. Currently, South Africa has 
three malaria endemic provinces with sustained annual local transmission-Limpopo, Mpumalanga and KwaZulu/Natal. Limpopo Province, which borders Zimbabwe to the north and Mozambique to the east, has the highest malaria incidence [3,4].

It was the discovery in 1898 that Anopheles mosquitoes are responsible for malaria parasite transmission [5], that spurred efforts to incriminate the specific local species responsible for primary transmission around the world. In South Africa, it was only in the mid 1920's that extensive initial surveys of mosquitoes were carried out in the previous Transvaal and Natal Provinces [6-8]. At the time nothing was known about the complexities of sibling species and the variable vectorial capacities within such species complexes. The work of Paterson [9,10], Davidson [11], Coluzzi [12], and others, using time-consuming cross-mating studies and chromosomal methods, did much to elucidate and unravel the species relationships in the 1960's and 70's.

Historically, for the first half of the 20th century prior to the introduction of regular annual indoor spraying of insecticides, Anopheles gambiae and Anopheles funestus were the main vectors of malaria in South Africa [2,6-8], but the concerted indoor control efforts resulted in local extinction of both species. Since then it has been widely believed that Anopheles arabiensis is the primary remaining vector responsible for malaria transmission in South Africa.

The malaria vector control programmes in the three endemic Provinces undertake annual application of indoor residual spraying (IRS) using a mosaic approach comprising two different classes of insecticides, pyrethroids and organochlorines. They also conduct vector surveillance which for decades has been limited largely to the An. gambiae complex, mainly by way of larval collections. Other Provinces, such as Northwest and Gauteng, experience significant levels of imported malaria cases but no local transmission.

Initially, the South African vector surveys included larval collections as well as human landing catches and indoor pyrethrum knockdowns, but in more recent years surveillance has focused on larval collections supplemented to some extent by adult pit-resting and container-resting (pots and jars) collections. Some provinces have the capacity to undertake their own molecular identification of the species complexes but support for identifications is provided largely by the National Institute for Communicable Diseases in Johannesburg.

Limpopo Province presents a pernicious residual malaria challenge for which the causal reasons remain unknown, especially as annual IRS is rigorously applied and is combined with active surveillance to detect infection sources and rapid treatment of all passive and actively diagnosed cases. This paper reports on a literature review of the historic species composition of Anopheles mosquitoes in Limpopo Province, and on current species composition and abundance based on independent mosquito collections carried out in 2017/18 in the far north-eastern region of the Province. We discuss the implications of these findings on malaria transmission in the area

\section{Materials and Methods}

\subsection{Study Area}

This study took place in the malaria endemic region of northern South Africa in what is currently known as Limpopo Province, one of four sub-divisions of what was previously the much larger "Transvaal" Province. Historically, malaria was present over a significantly larger area but sustained malaria control interventions dating back nearly 90 years has shrunk this malaria endemic region considerably [4]. The general Limpopo Province region was the focus for the literature review.

Within Limpopo Province, the Vhembe Municipal District is the area most heavily impacted by malaria in South Africa. It is located in the extreme north-eastern region of South Africa directly adjoining Zimbabwe and Mozambique, countries with which there is substantial trans-border movement of people, such as temporary migrant workers. The low-lying Limpopo River valley within this north-eastern corner has a high annual malaria incidence (in the context of South Africa), and we conducted mosquito surveillance in or near rural settlements or settings known for high 
malaria risk, plus random catches in the general Limpopo River valley area for comparative purposes (Figure 1). The sites we used for core sampling were Bende Mutale $\left(22^{\circ} 25.117^{\prime} \mathrm{S}, 31^{\circ} 02.016^{\prime} \mathrm{E}\right)$, Popallin Ranch $\left(22^{\circ} 21.248^{\prime} S, 30^{\circ} 35.434^{\prime}\right.$ E) and the worker village at Doreen Farms $\left(22^{\circ} 30.277^{\prime}\right.$ S, 30 $30^{\circ} 14.119^{\prime}$ E). We also report findings of opportunistic comparative catches at Tshipise tourist resort $\left(22^{\circ} 36.360^{\prime} \mathrm{S}\right.$, $\left.30^{\circ} 10.403^{\prime} \mathrm{E}\right)$, and in the Kruger National Park at Pafuri (Crook's Corner) $\left(22^{\circ} 26.445^{\prime} \mathrm{S}, 31^{\circ} 18.719^{\prime} \mathrm{E}\right)$ and Malahlapanga hot spring $\left(22^{\circ} 53.374^{\prime} \mathrm{S}, 31^{\circ} 02.391^{\prime} \mathrm{E}\right)$.

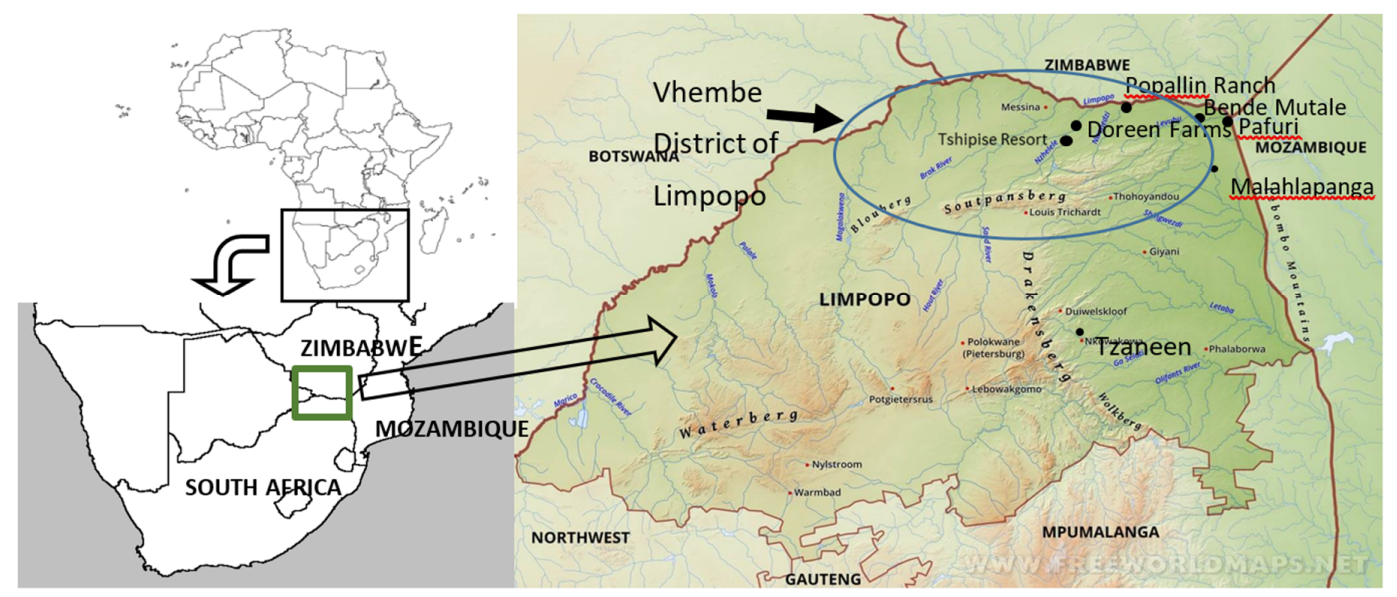

Figure 1. Limpopo River Valley study area.

\subsection{Data Sources}

We conducted a literature search using Google Scholar and PubMed. Keywords used were "Malaria AND South Africa" as well as "Malaria AND vectors AND South Africa". Timeframe was not specified, therefore accessing all records ever published, at least those accessible by the two search platforms used. Titles and abstracts of the search finds were then examined for relevance, and appropriate ones examined further. The most useful of these papers relevant to this study are summarized in Table 1.

Table 1. Summary of key publications providing data on vectors for Limpopo Province, South Africa, and immediate neighboring regions.

\begin{tabular}{|c|c|c|c|}
\hline Author(s) [Reference] & Date & Outline of Publication Content & Key Findings \\
\hline Ingram \& De Meillon [6] & 1927 & $\begin{array}{l}\text { Mosquito survey in 1926, results covering } \\
\text { northern Transvaal (the current Limpopo } \\
\text { Province) and coastal Zululand (current } \\
\text { KwaZulu-Natal), indicating distribution } \\
\text { and breeding sites (larval collections having } \\
\text { been the primary survey tool), with } \\
\text { discussion around malaria vector species } \\
\text { and control options. }\end{array}$ & $\begin{array}{l}\text { Thirteen anopheline species/species groups } \\
\text { found, speculating that } A n \text {. funestus and } \\
\text { An. gambiae are the main vectors despite strongly } \\
\text { fluctuating population numbers and apparent } \\
\text { extended absence even during malaria } \\
\text { transmission periods. }\end{array}$ \\
\hline Ingram \& De Meillon [7] & 1929 & $\begin{array}{l}\text { Mosquito survey in 1928, results covering } \\
\text { northern and eastern Transvaal (Limpopo } \\
\text { and Mpumalanga Provinces respectively) } \\
\text { with discussion around malaria vector } \\
\text { species and control options. }\end{array}$ & $\begin{array}{l}\text { Thirteen anopheline species found, mostly } \\
\text { through larval collections. }\end{array}$ \\
\hline Swellengrebel et al. [2] & 1931 & $\begin{array}{l}\text { Survey of anophelines in different habitat } \\
\text { settings in "Transvaal" and "Zululand" to } \\
\text { detect parasite positivity rates. }\end{array}$ & $\begin{array}{l}\text { Six Anopheles species found indoors, and malaria } \\
\text { parasites found in An. funestus, An. gambiae and } \\
\text { also An. pretoriensis. }\end{array}$ \\
\hline Steyn et al. [13] & 1955 & $\begin{array}{l}\text { Two-week survey in March } 1953 \text { of mainly } \\
\text { culicine mosquitoes by way of mostly larval } \\
\text { collections, in the general area from } \\
\text { Vaalwater to Musina in current } \\
\text { Limpopo Province }\end{array}$ & $\begin{array}{l}538 \text { mosquito specimens making up } 21 \text { species in } \\
\text { three genera (Anopheles } 6 \text { species; Aedes } 9 \text { spp.; } \\
\text { Culex } 6 \text { spp.) }\end{array}$ \\
\hline
\end{tabular}


Table 1. Cont.

\begin{tabular}{|c|c|c|c|}
\hline Author(s) [Reference] & Date & Outline of Publication Content & Key Findings \\
\hline $\begin{array}{c}\text { La Grange \& Coetzee } \\
\text { [14] }\end{array}$ & 1997 & $\begin{array}{l}\text { Anopheline survey } 1987-1989 \text { in Thomo } \\
\text { Village, Limpopo Province, using human } \\
\text { landing catches, outdoor resting catches, } \\
\text { and larval rearing. }\end{array}$ & $\begin{array}{l}\text { Exophilic members of Anopheles funestus group } \\
\text { most abundant, comprising } 85.8 \% \text { of total } \\
\text { Anopheles catch }(n=23,252) \text {. Of Anopheles landing } \\
\text { on humans, An coustani was most abundant at } \\
70.1 \%(n=2994) \text {, followed by members of the } \\
\text { An. funestus group at } 28.1 \% \text {. Of An. gambiae } \\
\text { complex captured }(n=245) \text { or reared }(n=225) \text {, } \\
155 \text { and } 164 \text { respectively were An. quadriannulatus. } \\
\text { No An. arabiensis were found. }\end{array}$ \\
\hline Govere et al. [15] & 2000 & $\begin{array}{l}\text { Monthly collections of Anopheles at } 7 \text { sites in } \\
\text { the Lowveld region of Mpumalanga } \\
\text { Province, August 1997-May 1998, using } \\
\text { human landing catches, window exit traps, } \\
\text { and indoor knockdown spraying. }\end{array}$ & $\begin{array}{l}\text { A total of } 5084 \text { Anopheles were collected, of which } \\
2837(55.8 \%) \text { were An. coustani, } 1418(27.9 \%) \\
\text { An. funestus group, } 435(8.6 \%) \text { An. gambiae } \\
\text { complex, } 264(5.2 \%) \text { An. pretoriensis and } 130 \\
(2.6 \%) \text { a mix of other anopheline species. Of the } \\
\text { An. gambiae complex, An. merus ( } 56 \%) \text { and } \\
\text { An. quadriannulatus ( } 30.4 \%) \text { dominated, with } \\
\text { An. arabiensis making up } 13.6 \% \text {. }\end{array}$ \\
\hline Munhenga et al. [16] & 2014 & $\begin{array}{l}\text { Anopheline species collected from five sites } \\
\text { over two years in the northern Kruger } \\
\text { National Park as part of an assessment of } \\
\text { sites for possible sterile male release for } \\
\text { malaria vector control. }\end{array}$ & $\begin{array}{l}\text { A total of } 3311 \text { anophelines comprising nine } \\
\text { species, showing clear and consistent differences } \\
\text { in Anopheles community composition between } \\
\text { sites even relatively close to each other. }\end{array}$ \\
\hline Cornel et al. [17] & 2018 & $\begin{array}{l}\text { Description of mosquito diversity and } \\
\text { abundance at multiple sites across southern } \\
\text { Africa, including Shingwedzi and Lapalala } \\
\text { Nature Reserve in Limpopo Province. }\end{array}$ & $\begin{array}{l}\text { Eight species of Anopheles comprising } 63.1 \% \text { of } \\
\text { the total catch of } 168 \text { mosquitoes at Shingwedzi. }\end{array}$ \\
\hline
\end{tabular}

\subsection{Vector Surveillance and Methods Used for New Data Presented Here}

Vector surveillance was targeted at known high-incidence and recurring malaria "hotspots" in the eastern Limpopo River valley region of Vhembe District. Collections were made in October and December 2017 and again in February, April and October 2018. Adult mosquitoes were collected using $\mathrm{CO}_{2}$-baited light traps and tent traps baited with dry ice $\mathrm{CO}_{2}$, cows and sometimes goats (Figure 2), and occasionally human landing catches. Ethics approval for human landing catches and for use of cattle as bait in tent traps were obtained from the University of Pretoria (code H015-17). In addition, larval collections were made from a wide range of pools along river edges or other forms of surface water, using the standard dip method or surface sweep-netting [18]. In most cases only Anopheles mosquitoes were identified to species level and other culicines recorded at genus level, although when time and expertise was available these other non-anophelines were also identified to species. Anopheles specimens were all—except for unidentifiable damaged specimens-microscopically identified to species or species group/complex within hours after capture, using standard reference keys [19]. All anophelines were placed individually in silica-gel reaction tubes for Polymerase Chain Reaction (PCR) species identification of members of the An. funestus group [20] and the An. gambiae complex [21], and subsequent testing for sporozoites [22]. 

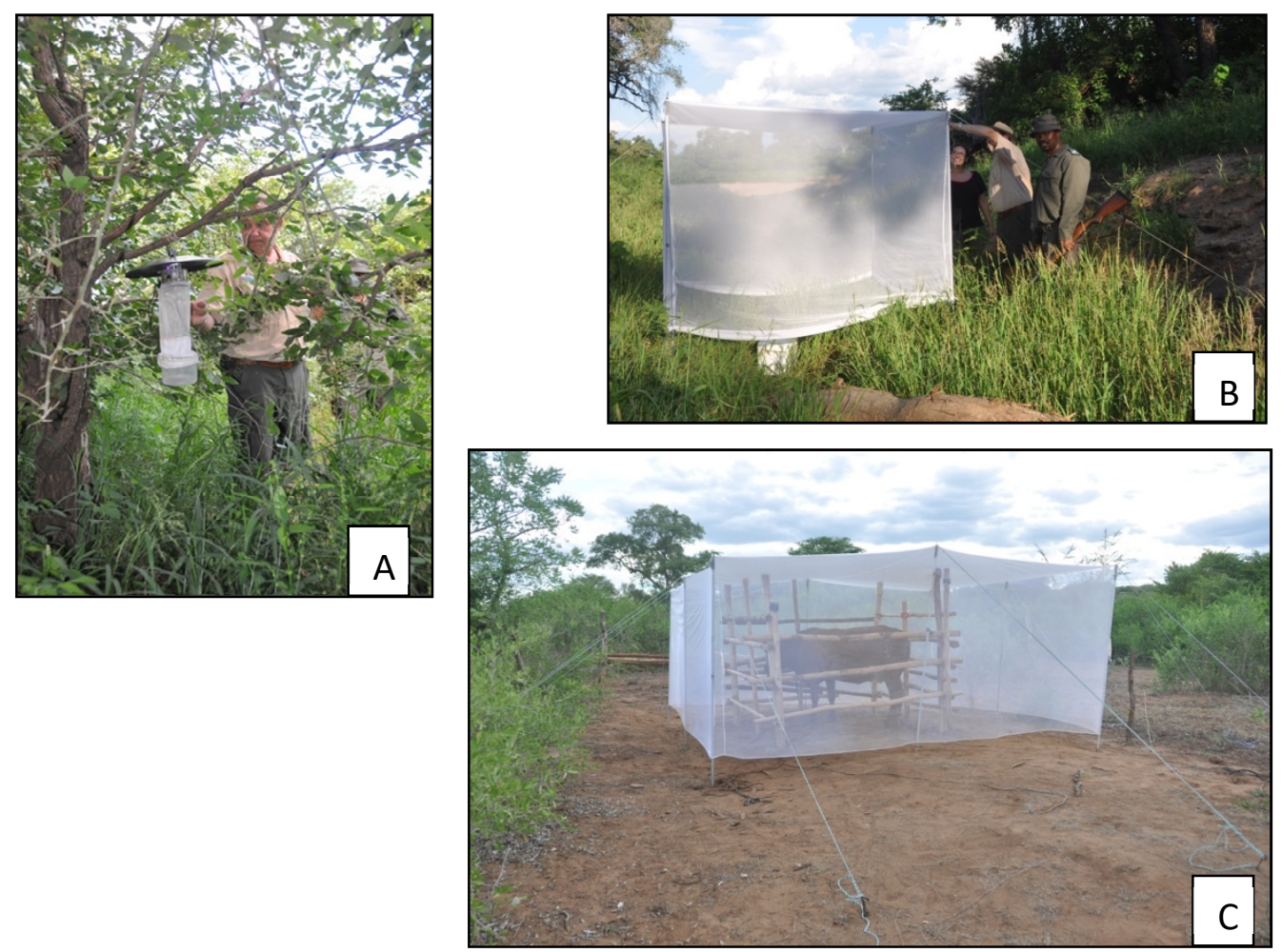

Figure 2. Trap types deployed during current study: (A)- $\mathrm{CO}_{2}$-baited $\mathrm{CDC}$ light trap; (B) - $\mathrm{CO}_{2}$-baited tent trap; (C)—cow-baited tent trap.

\section{Results}

The publications providing insight and understanding of malaria vectors and associated mosquito communities over almost a full century of research and surveillance in what is now the Limpopo Province of South Africa, are sufficiently few that the findings in each can be summarized below.

\subsection{Historical Surveys in Limpopo Province}

The first records reflecting Anopheles species composition and some idea of distribution and general abundance are those of Ingram and De Meillon [6,7], published in 1927 and 1929. They report on mosquito surveys conducted along the railway lines in the "northern Transvaal" (Limpopo Province) and "eastern Transvaal" (Mpumalanga Province), and along the coastal belt of Zululand (the northern regions of KwaZulu-Natal Province). These publications are the first detailed surveys with published reports of mosquitoes in what is now Limpopo Province, no significant collections having been undertaken prior to that, as corroborated by these authors. In their coverage of the "northern Transvaal" in 1926 and 1928, they recorded a total of 16 anopheline species (Table 2). Their records of "An. funestus" and "An. gambiae" would have included some of the other species now known to occur within these groups/complexes, and in January 1928 they recorded "An. gambiae var. quadriannulatus" from Leydsdorp (near Tzaneen, Figure 1). Based largely on the known status of these two malaria vector groups as primary vectors elsewhere in Africa, they suggested that these were likely to be the main vectors in South Africa, despite the curious anomaly of long periods of undetectable presence of either species in areas experiencing malaria transmission, in the case of "An. gambiae" even for 3 or 4 years in succession. That anomaly remains relevant today. 
Table 2. Survey of anopheline mosquitoes from the malaria endemic regions in the northern (Limpopo Province) and north-eastern (Mpumalanga Province) “Transvaal" [6,7]. P = present.

\begin{tabular}{|c|c|c|c|c|c|c|c|}
\hline Species & $\begin{array}{c}\text { Zoutpans-Berg } \\
1926\end{array}$ & $\begin{array}{c}\text { Zoutpans-Berg } \\
1928\end{array}$ & $\begin{array}{c}\text { Waterberg } \\
1926\end{array}$ & $\begin{array}{c}\text { Waterberg } \\
1928\end{array}$ & $\begin{array}{c}\text { Skukuza } \\
1928\end{array}$ & $\begin{array}{c}\text { Tzaneen } \\
1928\end{array}$ & $\begin{array}{c}\text { Musina } \\
1928\end{array}$ \\
\hline An. cinereus & & & $\mathrm{P}$ & $\mathrm{P}$ & & $\mathrm{P}$ & \\
\hline An. coustani & $\mathrm{P}$ & $\mathrm{P}$ & $\mathrm{P}$ & $\mathrm{P}$ & $\mathrm{P}$ & $\mathrm{P}$ & \\
\hline An. demeilloni & $\mathrm{P}$ & & & $\mathrm{P}$ & & $\mathrm{P}$ & \\
\hline An. funestus group & $\mathrm{P}$ & $\mathrm{P}$ & & $\mathrm{P}$ & $\mathrm{P}$ & $\mathrm{P}$ & \\
\hline $\begin{array}{l}\text { An. gambiae } \\
\text { complex }\end{array}$ & $\mathrm{P}$ & $\mathrm{P}$ & & $\mathrm{P}$ & $\mathrm{P}$ & $\mathrm{P}$ & $\mathrm{P}$ \\
\hline An. longipalpis & $\mathrm{P}$ & $\mathrm{P}$ & & $\mathrm{P}$ & & $\mathrm{P}$ & \\
\hline An. maculipalpis & $P$ & & & & & & \\
\hline An. marshallii & & & & $\mathrm{P}$ & & $\mathrm{P}$ & \\
\hline An. natalensis & $\mathrm{P}$ & & & & & $\mathrm{P}$ & \\
\hline An. nili & & & & & $\mathrm{P}$ & & $\mathrm{P}$ \\
\hline An. pretoriensis & & $\mathrm{P}$ & $\mathrm{P}$ & $\mathrm{P}$ & $\mathrm{P}$ & $\mathrm{P}$ & $\mathrm{P}$ \\
\hline An.quadriannulatus & & & & & & $\mathrm{P}$ & \\
\hline An. rhodesiensis & & $\mathrm{P}$ & $\mathrm{P}$ & $\mathrm{P}$ & $\mathrm{P}$ & & $\mathrm{P}$ \\
\hline An. rufipes & $\mathrm{P}$ & $\mathrm{P}$ & $\mathrm{P}$ & $\mathrm{P}$ & $\mathrm{P}$ & $\mathrm{P}$ & $\mathrm{P}$ \\
\hline An. squamosus & & $\mathrm{P}$ & $\mathrm{P}$ & $\mathrm{P}$ & & $\mathrm{P}$ & \\
\hline An. theileri & & & $\mathrm{P}$ & $\mathrm{P}$ & & & \\
\hline
\end{tabular}

Despite being limited in scope and duration, the survey by Swellengrebel et al. [2] yielding 877 anophelines in the "Transvaal" to determine parasite presence in Anopheles species, does present useful information, summarized in Table 3. They discuss six species of Anopheles collected mostly from inside human dwellings, of which Plasmodium parasites were recovered commonly from An. funestus and An. gambiae in two different locations and also from An. pretoriensis collected both inside and outside houses in the Letaba foothills outside Tzaneen (Figure 1). These results also confirmed the distribution of the two vector groups, with An. funestus being restricted to the foothills along the mountain range and members of the An. gambiae complex more prevalent in the lowland areas. Later studies provided evidence for the restricted distribution of An. funestus being due to its preferred larval habitat of small streams or rivers in the area [8].

Table 3. Parasite infections in Anopheles surveyed in the "Transvaal" in 1931 by Swellengrebel et al. [2].

\begin{tabular}{|c|c|c|c|c|}
\hline \multirow[b]{2}{*}{ Species } & \multicolumn{3}{|c|}{ Letaba Foothills } & \multirow[b]{2}{*}{$\begin{array}{c}\text { Ofcolaco } \\
\text { Inside Rural Huts } \\
\text { in Lowland Area } \\
\text { Number of } \\
\text { Mosquitoes } \\
\text { (Number } \\
\text { Parasite-Infected) }\end{array}$} \\
\hline & $\begin{array}{l}\text { Inside Rural Huts } \\
\text { in Foothills } \\
\text { Number of } \\
\text { Mosquitoes } \\
\text { (Number } \\
\text { Parasite-Infected) }\end{array}$ & $\begin{array}{c}\text { Inside Rural } \\
\text { Farmhouses } \\
\text { Number of } \\
\text { Mosquitoes } \\
\text { (Number } \\
\text { Parasite-Infected) }\end{array}$ & $\begin{array}{l}\text { Outside Rural } \\
\text { Farmhouses } \\
\text { Number of } \\
\text { Mosquitoes } \\
\text { (Number } \\
\text { Parasite-Infected) }\end{array}$ & \\
\hline An. funestus group & $240(44)$ & $44(6)$ & $7(0)$ & $53(0)$ \\
\hline An. gambiae complex & $6(0)$ & - & $1(0)$ & $161(27)$ \\
\hline An. maculipalpis & - & $1(0)$ & - & - \\
\hline An. marshallii & - & - & - & $1(0)$ \\
\hline An. pretoriensis & $9(0)$ & $1(1)$ & $110(1)$ & - \\
\hline An. rufipes & $4(0)$ & - & $14(0)$ & $1(0)$ \\
\hline
\end{tabular}

Steyn et al. [13] report on a total of 538 mainly culicine mosquitoes collected during a March 1953 survey along the upper Limpopo River Valley between Vaalwater and Pafuri (Figure 1). The focus of the survey was to understand culicine mosquito composition in the area, and the emphasis was on larval collections, especially tree-hole breeding sites. Three genera comprising 21 species of mosquitoes were collected, including six species of Anopheles, nine of Aedes and six Culex (Table 4). This is the only historical survey recording the presence of An. listeri, collected to the east of Musina close to where the current survey was conducted. 
Table 4. Findings of a 1953 survey of mosquitoes in the upper Limpopo River Valley [13].

\begin{tabular}{cccc}
\hline Species & Larvae & Adults & Total \\
\hline Anopheles coustani & 7 & 2 & 9 \\
An. gambiae complex & 23 & 3 & 26 \\
An. listeri & 19 & - & 19 \\
An. rufipes & 2 & 1 & 3 \\
An. pretoriensis & 12 & 1 & 13 \\
An. squamosus & - & 1 & 1 \\
Aedes spp. (scatophagoides, fulgens, aegypti, metallicus, & 257 & 71 & 328 \\
calceatus, vittatus, marshalli, dentatus, hirsutus) & & & 139 \\
Culex spp. (tigripes, nebulosus var. pseudocinereus, & 88 & 51 & 538 \\
theileri, univittatus, simpsoni, decens) & 408 & 130 & \\
Totals &
\end{tabular}

The paper by La Grange and Coetzee [14] is especially useful as it reports on a detailed list of anopheline species collected using four different methods over a 27-month June 1987-August 1989 period in the village of Thomo, Limpopo Province (near Giyani Figure 1). Direct comparisons of anopheline species composition and relative abundance can therefore be made with the October 2017-October 2018 survey conducted in Vhembe District as reported below. Catch details for the $1987 / 89$ collections are provided in Table 5. Of the 23,252 anophelines collected, $85.8 \%$ comprised members of the An. funestus group (no identifications of specific species was done), while members of the An. gambiae complex made up a mere $1.05 \%(n=245$, of which a sample of 155 were identified electrophoretically [23] as An. quadriannulatus. Of the 2994 anophelines (11 species) caught by human landing catches, $70.1 \%$ were $A n$. coustani and $28.1 \%$ An. funestus group, with only six individuals belonging to the An. gambiae complex (0.2\%). No An. arabiensis were identified in the 155 processed for electrophoretic identification.

Table 5. Anopheles mosquitoes collected from Thomo village, Limpopo Province, from June 1987 to August 1989 [14]. F = females; M = males; HLC = human landing catches; Pit = pit collections; Natural $=$ natural refuges.

\begin{tabular}{cccccccc}
\hline Species & HLC & Pit F & Pit M & Natural F & Natural M & Cattle Enclosures & Total \\
\hline An. funestus group & 842 & 9234 & 6807 & 1819 & 1099 & 157 & 19,958 \\
An. gambiae complex & 6 & 45 & 20 & 115 & 51 & 8 & 245 \\
An. coustani & 2100 & 3 & 3 & 9 & 1 & 21 & 2137 \\
An. rufipes & 6 & 41 & 22 & 343 & 361 & 24 & 797 \\
An. squamosus & 25 & - & - & 1 & - & 6 & 32 \\
An. pretoriensis & - & - & 1 & 17 & 11 & - & 29 \\
An. marshallii & 2 & 2 & - & 5 & - & 3 & 7 \\
An. pharoensis & 4 & - & - & - & - & 1 & 13 \\
An. longipalpis & 5 & 4 & - & 3 & - & 3 & 8 \\
An. demeilloni & 1 & 2 & - & 2 & - & 9 & 14 \\
An. maculipalpis & 2 & - & - & 3 & - & 1 & 2 \\
An.theileri & 1 & - & - & - & - & 234 & 23,252 \\
Totals & 2994 & 9331 & 6853 & 2317 & 1523 & & \\
\hline
\end{tabular}

The northern half of the roughly $19,000 \mathrm{~km}^{2}$ Kruger National Park (KNP) forms part of Limpopo Province and is located as a pristine, untransformed wedge of land between Mozambique and the rest of Limpopo Province. This northern part of the KNP has been the target of several mosquito surveys in recent decades, some focused on the unique freshwater spring Malahlapanga which offers ideal breeding conditions for select members of the An. gambiae complex [16,24-26], and also along the Shingwedzi River in very different dense woodland settings [17]. The collections from these various surveys offer interesting comparative insights with collections in more transformed settings elsewhere in Limpopo Province. At the Malahlapanga freshwater spring, with water slowly bubbling out at $37^{\circ} \mathrm{C}$ and forming numerous footprint pools in the shallow overflow stream where animals come 
to drink, several publications [16,24,26] report on the strong presence of An. arabiensis since the late 1980s, to the near total exclusion of other members An. gambiae complex. This state of An. arabiensis dominance continued until about 2012, as reflected in surveys by Munhenga et al. [16] between July 2010 and December 2012 (Table 6), but for unknown reasons the population then rapidly changed to being dominated by An. quadriannulatus (Braack, Munhenga, personal observations). Nevertheless, for purposes of this paper, the findings of the Munhenga et al. 2014 survey [16] serve as a useful reference point and are summarized in Table 6 . It should be pointed out that very distinct differences existed in the Anopheles communities associated with each of these five sites.

Table 6. Anopheles mosquitoes collected from five sites in the northern Kruger National Park, Limpopo Province, July 2010 to December 2012 [16].

\begin{tabular}{cccc}
\hline Species & Total Collected & $\begin{array}{c}\text { Percentage Composition } \\
\text { Aggregate of Specimens } \\
\text { Caught at All Sites) }\end{array}$ & $\begin{array}{c}\text { Number of Sites } \\
\text { Collected from }\end{array}$ \\
\hline An. arabiensis & $1352^{* *}$ & 44.3 & 3 \\
An. quadriannulatus & 870 & 28.5 & 4 \\
An. merus & $349^{* * *}$ & 11.4 & 2 \\
An. coustani & 395 & 12.9 & 3 \\
An. pretoriensis & 35 & 1.1 & 2 \\
An. maculipalpis & 28 & 0.9 & 2 \\
An. rivulorum & 19 & 0.6 & 1 \\
An. squamosus & 3 & 0.1 & 1 \\
An.rufipes & 2 & 0.1 & 2 \\
\hline
\end{tabular}

** of which $99.6 \%$ collected at one site, Malahlapanga freshwater spring. ${ }^{* * *}$ of which $98.9 \%$ collected at the two salt-water springs Mafayeni \& Matiovila.

With the exception of Malahlapanga with its unique attributes affording an ideal breeding opportunity for An. arabiensis (99.6\% of the 1352 specimens collected), this species was very rare at all the other sites. Similarly, $98.6 \%$ of 348 An. merus were caught at the two salt-water springs Mafayeni and Matiovila, in line with their larval biology. Also interesting, despite the relatively isolated nature of Malahlapanga, having no connection with nearby watercourses for much of the year and its setting dominated by monotonous mopane-woodland, this site had the highest diversity of anopheline species (all nine species were found here). It also had the highest numbers (75.4\% of overall total mosquitoes captured at all sites) whereas the site "Louis-se-Gat" adjoining the Shingwedzi River, with diverse and lush riverine forest frequented by an abundance of diverse mammals and birds, yielded only $4.6 \%$ of the total catch.

Cornel et al. [17] at Shingwedzi in this northern part of the Kruger National Park, collected 168 mosquitoes comprising 20 species in five genera during three nights of collections using $\mathrm{CO}_{2}$-baited net traps and light traps. Of the 20 species, eight were Anopheles (Table 7 ) accounting for $65 \%$ of the total catch. Cornel et al. also sampled mosquitoes in the Lapalala Nature Reserve in the western interior region of Limpopo Province, using $\mathrm{CO}_{2}$-baited net traps and light traps over four nights. Here they collected a total of 296 mosquitoes comprising 19 species in five genera. Of these, five species were Anopheles, comprising 49\% of all mosquitoes captured (Table 7). No An. arabiensis was recorded from either site. 
Table 7. Anopheles species collected by $\mathrm{CO}_{2}$-baited net and light traps at Shingwedzi, Kruger National Park and Lapalala Nature Reserve, Limpopo Province in 2015 [17].

\begin{tabular}{|c|c|c|c|c|}
\hline Locality & Anopheles (n) & No. Culex & $\begin{array}{c}\text { No. Other } \\
\text { Genera }\end{array}$ & Summary \\
\hline $\begin{array}{l}\text { Shingwedzi River, } \\
\text { Kruger National } \\
\text { Park, eastern } \\
\text { Limpopo Province }\end{array}$ & $\begin{array}{c}\text { An. leesoni (2) } \\
\text { An. parensis (1) } \\
\text { An. pharoensis (3) } \\
\text { An. quadriannulatus (66) } \\
\text { An. rivulorum (6) } \\
\text { An. rivulorum-like (26) } \\
\text { An. squamosus (4) } \\
\text { An. theileri (1) } \\
\text { Total: } 109\end{array}$ & 25 & 34 & $\begin{array}{c}109 \text { Anopheles out } \\
\text { of } 168 \text { mosquitoes } \\
=65 \%\end{array}$ \\
\hline $\begin{array}{l}\text { Lapalala Nature } \\
\text { Reserve, western } \\
\text { Limpopo Province }\end{array}$ & $\begin{array}{l}\text { An. coustani (41) } \\
\text { An. longipalpis (1) } \\
\text { An. marshallii (54) } \\
\text { An. squamosus (6) } \\
\text { An. theileri (42) } \\
\text { Total: } 144\end{array}$ & 43 & 109 & $\begin{array}{c}144 \text { Anopheles out } \\
\text { of } 296=49 \%\end{array}$ \\
\hline
\end{tabular}

\subsection{Surveys in Surrounding Areas}

For comparative purposes, it is useful to have a sense of Anopheles community composition in the neighboring malaria regions of Mpumalanga Province to the south, Zimbabwe to the north, and Mozambique to the east.

In Mpumalanga Province, Govere et al. [15] conducted monthly collections of mosquitoes at 7 sites in the Lowveld Region between August 1997 and May 1998 (Table 8). A total of 5084 Anopheles were collected of which An. coustani was by far the most abundant $(n=2837,55.8 \%)$, followed by the An. funestus group ( $n=1418,27.9 \%$, species not identified) and the An. gambiae complex $(n=435$, 8.6\%). Anopheles pretoriensis made up $5.2 \%$ of the total catch while the remaining $2.6 \%$ comprised of An. demeilloni, An. longipalpis, An. maculipalpis, An. marshallii, An. rufipes and An. squamosus. Members of the An. gambiae complex were An. merus (56\%), An. quadriannulatus (30.4\%) and An. arabiensis (13.6\%). However, more than $80 \%$ of the An. gambiae complex catch came from only one (Martiens) of the seven collection sites, thus distorting the interpretation of results, in particular the abundance of An. merus. ELISA assays for Plasmodium falciparum circumsporozoite antigen presence were negative for all An. gambiae complex members.

Table 8. Monthly human landing captures off eight humans sitting 18:00 to 22:00, usually four nights per month at seven sites in Mpumalanga Province, August 1997 to May 1998 [15].

\begin{tabular}{ccccccc}
\hline Month & $\begin{array}{c}\text { Sampling } \\
\text { Days (\%) }\end{array}$ & An. coustani & $\begin{array}{c}\text { An.funestus } \\
\text { Group }\end{array}$ & $\begin{array}{c}\text { An.gambiae } \\
\text { Complex }\end{array}$ & An.pretoriensis & $\begin{array}{c}\text { Other } \\
\text { Anopheles }\end{array}$ \\
\hline August 1997 & $15(12.0)$ & 809 & 579 & 6 & 20 & 9 \\
September & $17(13.6)$ & 650 & 321 & 8 & 9 & 1 \\
October & $20(16.0)$ & 518 & 227 & 63 & 5 & 18 \\
November & $17(13.6)$ & 291 & 212 & 95 & 14 & 7 \\
December & $8(6.4)$ & 142 & 0 & 53 & 35 & 15 \\
January 1998 & $14(11.2)$ & 105 & 12 & 117 & 17 & 6 \\
February & $15(12.0)$ & 251 & 23 & 77 & 60 & 13 \\
March & $7(5.6)$ & 55 & 6 & 3 & 44 & 7 \\
April & $4(3.2)$ & 14 & 6 & 4 & 39 & 14 \\
May & $8(6.4)$ & 2 & 32 & 9 & 21 & 40 \\
Total (\%) & $125(100.0)$ & $2837(55.8 \%)$ & $1418(27.9 \%)$ & $435(8.6 \%)$ & $264(5.2 \%)$ & $130(2.6 \%)$ \\
\hline
\end{tabular}


The high percentage of An. merus relative to other members of the An. gambiae complex reported in at least one area of Mpumalanga Province [15] was subsequently substantiated by a similar study undertaken by Mbokazi et al. [27], who found steadily increasing abundance of An. merus and greatly expanded distribution across Mpumalanga Province over a nine-year period, 2005 to 2014.

North of Vhembe District, Sande et al. [28] conducted anopheline surveys in the Mutare and Mutasa Districts of Manicaland Province, Zimbabwe, during the period November 2013 to April 2014. They sampled larvae in a range of habitat types and conducted indoor pyrethrum knockdown spray catches for adult anophelines each month. Approximately 4848 Anopheles larvae were collected yielding 4690 adults, of which $97.9 \%(n=4593)$ were An. pretoriensis, while An. funestus group members comprised 1.9\% $(n=87)$ and An. gambiae complex members $0.2 \%(n=10)$.

Cumulatively, considering all anophelines reared from larval collections and adults captured by way of knockdown catches indoors, members of the An. funestus group were 27 times more abundant than the An. gambiae complex. From a total of 840 An. funestus group females subjected to PCR assay [20], 90.8\% were An funestus, 5.1\% An. leesoni and the rest failed to amplify. Of 31 An. gambiae complex females assayed by PCR [21], $48.4 \%(n=15)$ were An. quadriannulatus, $41.9 \%$ An. arabiensis $(n=13)$ and $9.7 \%$ were unidentifiable.

In summary, An. arabiensis was present only in very low numbers over the entire period, with An. funestus being relatively more abundant but in terms of overall numbers also very low, especially in comparison with An. pretoriensis. A summary of mosquito catches is provided in Table 9. These findings confirm earlier reports of Masendu et al. [29] that showed dominance of An. pretoriensis over other anopheline species in Zimbabwe. However, the findings also contrasted with previous reports [30,31] that $A n$. arabiensis was the main vector in these regions, and instead indicated that unexplained population changes had occurred which resulted in An. funestus becoming more common and taking over as the probable main malaria vector, especially given its strong endophilic and anthropophagic habits.

Table 9. Species composition (\%) and abundance of anophelines captured by sampling method and locality in eastern Zimbabwe [28].

\begin{tabular}{|c|c|c|c|c|c|}
\hline $\begin{array}{l}\text { Sampling } \\
\text { Method }\end{array}$ & Sampling Region & $\begin{array}{c}\text { Total } \\
\text { Anopheles }\end{array}$ & $\begin{array}{l}\text { An. funestus } \\
\text { Group }\end{array}$ & $\begin{array}{l}\text { An. gambiae } \\
\text { Complex }\end{array}$ & An.pretoriensis \\
\hline \multirow{2}{*}{$\begin{array}{l}\text { Pyrethrum } \\
\text { spray catch }\end{array}$} & $\begin{array}{l}\text { Burma Valley Ward, } \\
\text { Mutare District }\end{array}$ & 795 & $96.6 \%$ & $3.3 \%$ & $0.1 \%$ \\
\hline & $\begin{array}{c}\text { Zindi Ward, } \\
\text { Mutasa District }\end{array}$ & 140 & $96.4 \%$ & $3.6 \%$ & $0 \%$ \\
\hline \multirow{2}{*}{$\begin{array}{l}\text { Reared from } \\
\text { larvae }\end{array}$} & $\begin{array}{l}\text { Burma Valley Ward, } \\
\text { Mutare District }\end{array}$ & 3141 & $1.4 \%$ & $0.2 \%$ & $98.4 \%$ \\
\hline & $\begin{array}{c}\text { Zindi Ward, } \\
\text { Mutasa District }\end{array}$ & 1549 & $2.9 \%$ & $0.2 \%$ & $96.9 \%$ \\
\hline Totals & & 5625 & $17.5 \%$ & $0.8 \%$ & $81.7 \%$ \\
\hline
\end{tabular}

Worth noting are the recent findings of Zengenene et al. [32], who report on limited collections of Anopheles adults and larvae from the Chiredzi District in Zimbabwe, directly adjacent to our Limpopo Valley study area and at collection sites located a relatively short distance of approximately $130-150 \mathrm{~km}$ from our primary sampling areas. From a total of 153 Anopheles collected, no specimens of An. arabiensis or An. merus were found, although An. quadriannulatus was common. Of the 16 members of the An. funestus group collected as adults, 14 (87.5\%) were An. funestus. Despite the small sample size, these findings are significant and are discussed below.

In neighboring southern Mozambique, Casimiro et al. [33] and Kyalo et al. [34] report on the presence of An. gambiae s.s. while An. funestus has been recorded by Brooke et al. [35] and Casimiro et al. [36,37]. 


\section{3. $2017 / 2018$ Vector Surveys}

Surveillance activities in the Limpopo Valley region of Vhembe District between October 2017 and October 2018 yielded a total of 2225 adult mosquitoes representing 8 genera, of which Anopheles constituted $64.9 \%(n=1443)$ of the total. Culex $(17.3 \%)$, Aedes $(13.2 \%)$ and Mansonia $(4.4 \%)$ made up most of the remaining numbers with a few specimens of Mimomyia, Coquellittidia and Aedeomyia also captured (Figure 3). Of the 1443 Anopheles captured, 1027 (71.2\%) belonged to four members of the An. gambiae complex (35.8\%) and six members of the An. funestus group (35.4\%). Eleven other species were collected with An. pretoriensis (9\%), An. rufipes (5.8\%) and An. listeri (3.5\%) being the most common (Figure 4$)$. The relatively small sample $(n=391)$ of adults reared from larval collections yielded a species abundance that largely reflects that of the adult collections (Figure 4), except for the An. funestus group, which featured very poorly in the larval collections reflecting the well-known difficulty of finding these larvae at low densities ([38], p. 134).

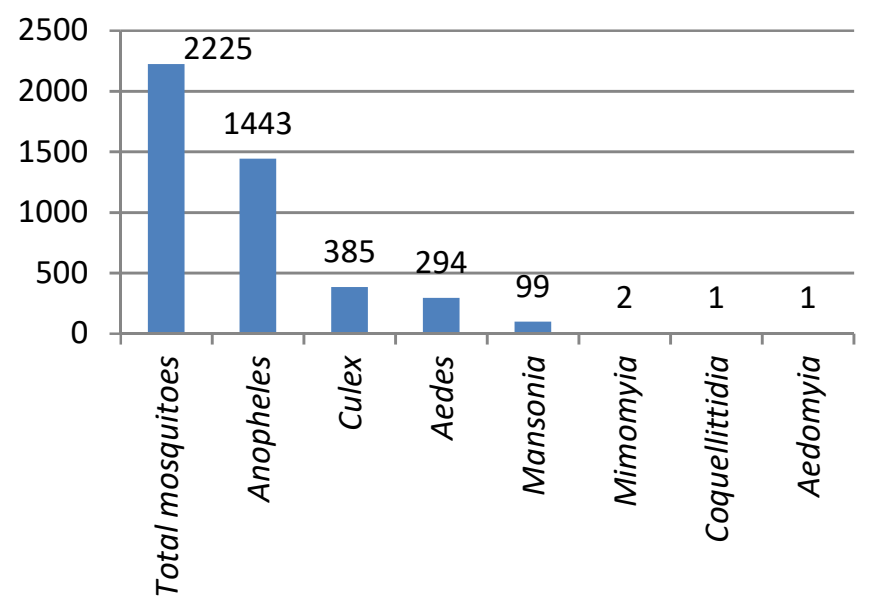

Figure 3. Mosquito numbers by genera: total adults collected October 2017-October 2018.

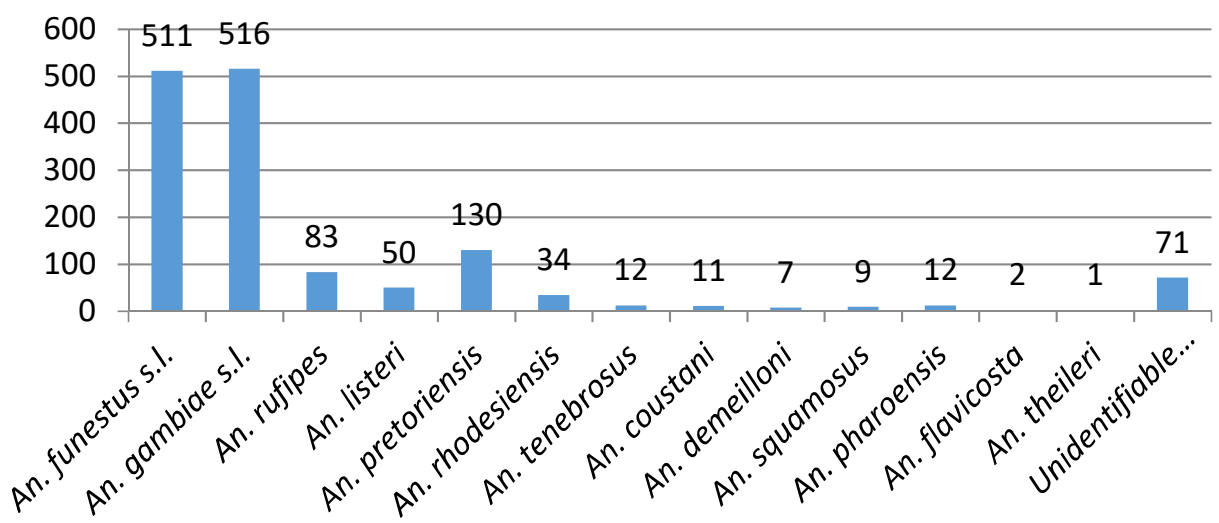

Figure 4. Mosquito numbers by Anopheles species: adults and larvae collected October 2017 to October 2018.

Of the 511 An. funestus group collected, 408 individuals were successfully assayed by PCR [20] for species separation (Table 10). Considered collectively across all sites and all sampling months, An. rivulorum formed the overwhelming majority $(n=312)$. 
Table 10. Polymerase Chain Reaction-identified Anopheles species collected in the northern Limpopo Province, South Africa.

\begin{tabular}{|c|c|c|c|c|c|c|c|c|c|c|c|}
\hline Locality & $\begin{array}{l}\text { Sampling } \\
\text { Month }\end{array}$ & An.funestus & An. leesoni & An.parensis & An. rivulorum & An.rivulorum-Like & An. vaneedeni & An. gambiae s.s. & An. arabiensis & An. quadriannulatus & An. merus \\
\hline Bende Mutale & Feb 2018 & - & 3 & - & 165 & 3 & - & - & - & - & - \\
\hline Bende Mutale & Apr 2018 & - & 2 & - & 2 & 9 & - & - & 1 & 59 & 6 \\
\hline Bende Mutale & Oct 2018 & - & 7 & 2 & 7 & - & - & - & - & 35 & 1 \\
\hline Popallin Ranch & Oct 2017 & - & 2 & - & 47 & - & - & - & - & - & - \\
\hline Popallin Ranch & Feb 2018 & 1 & 1 & 2 & 29 & - & 1 & 1 & - & - & - \\
\hline Popallin Ranch & Apr 2018 & - & 2 & - & 54 & 7 & - & - & - & 4 & 1 \\
\hline Doreen Farms & Feb 2018 & - & - & - & 5 & - & 2 & - & - & - & - \\
\hline Doreen Farms & Apr 2018 & - & 4 & - & 2 & - & 1 & - & 1 & 10 & - \\
\hline Tshipise Resort & Apr 2018 & - & 4 & - & 1 & 1 & 42 & - & 1 & - & - \\
\hline Nkotswi & Apr 2018 & - & - & - & - & - & - & - & - & 7 & - \\
\hline Tshikuyu & Apr 2018 & - & - & - & - & - & - & - & - & 1 & - \\
\hline Pafuri & Apr 2018 & - & - & - & - & - & - & - & 3 & 27 & - \\
\hline Malahla-panga & Oct 2018 & - & - & - & - & - & - & - & 42 & 7 & - \\
\hline Total & & 1 & 25 & 4 & 312 & 20 & 46 & 1 & 48 & 150 & 8 \\
\hline
\end{tabular}


A single specimen of An. funestus was collected at the Popallin Ranch tourist lodge in February 2018. This was somewhat unexpected as An. funestus is generally regarded to have been eliminated from Limpopo Province for decades due to regular and widespread application of indoor residual application of Dichlorodiphenyltrichloroethane (DDT) in this region. However, its identity is confirmed and An. funestus is known to occur commonly in neighboring Zimbabwe at sampling sites approximately $130 \mathrm{~km}$ away [32]. While An. rivulorum was the dominant species of the group across most sites, at the Tshipise tourist resort An. vaneedeni comprised 88\% in April 2018 (Table 10). These were collected from two $\mathrm{CO}_{2}$-baited Centres for Disease Control and Prevention (CDC) light traps placed alongside a wetland overgrown with a dense stand of reeds (Phragmites australis (Cav.) Trin. ex Steud.), adjoining the camping area.

Of the 516 An. gambiae complex collected, 207 specimens were assayed by PCR [21]. Of these, $150(72.5 \%)$ were An. quadriannulatus, $48(23.2 \%)$ An. arabiensis and 8 (3.9\%) An. merus (Table 10). Of the 48 An. arabiensis collected over the one-year period, 42 were collected during a single night of sampling in October 2018 at the Malahlapanga freshwater spring in the Kruger National Park. One single specimen of PCR-determined An. gambiae s.s. was collected at Popallin Ranch in February 2018. Anopheles gambiae s.s. is known to have occurred historically widely across southern Africa [25], including the northern parts of South Africa $[39,40]$.

Figure 5 depicts the relative abundance of Anopheles species collected at the three core sampling areas of Doreen Farms, Popallin Ranch, and Bende Mutale and at the opportunistic sampling sites of Tshipise tourist lodge, Pafuri, and Malahlapanga. The percentage contribution of the An. funestus group and An. gambiae complex for five sites (excluding Malahlapanga) is shown in Figure 6. 
A

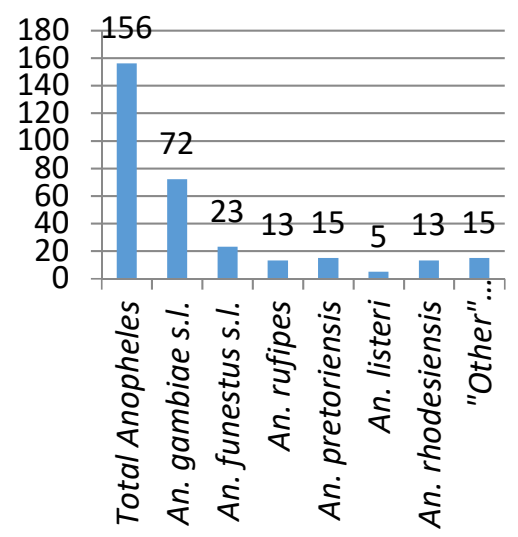

D

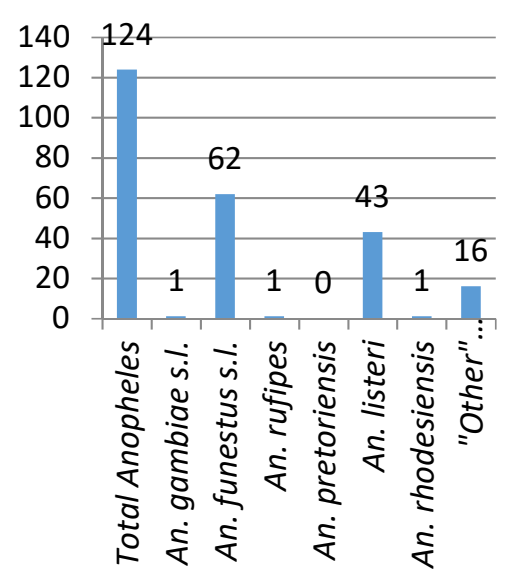

B

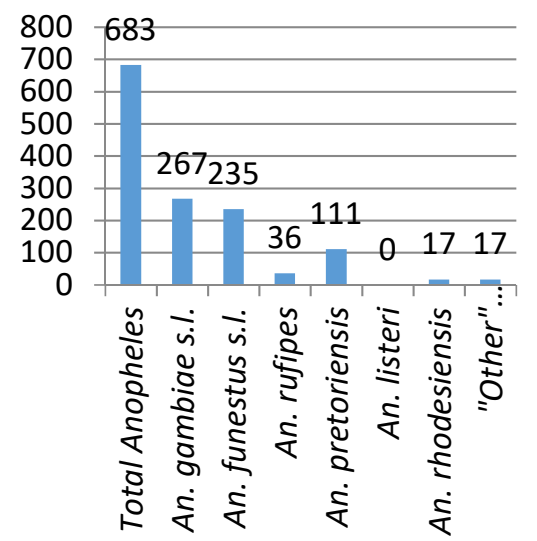

E

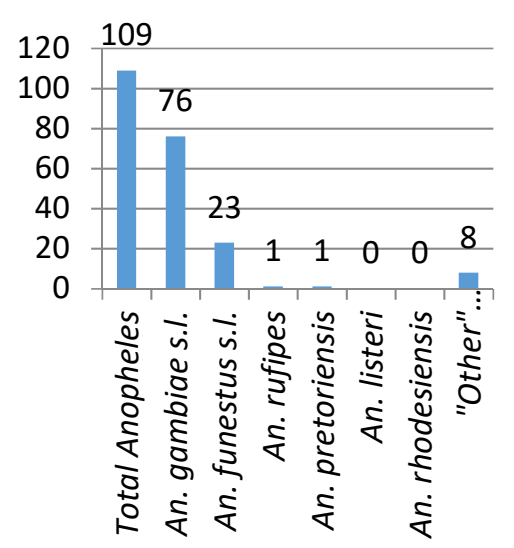

C

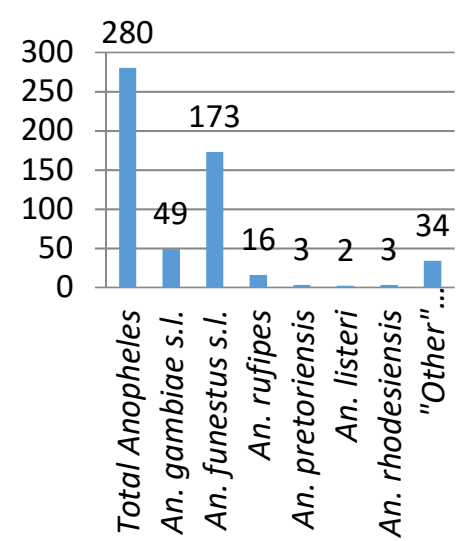

F

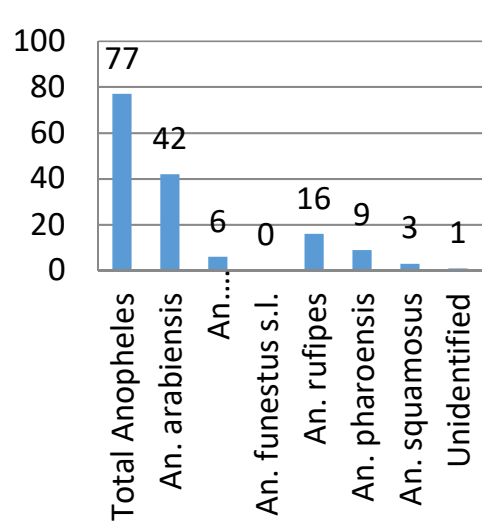

Figure 5. Adult Anopheles collected in 2017/18 at six localities: (A) Doreen Farms; (B) Bende Mutale; (C) Popallin Ranch; (D) Tshipise Resort; (E) Pafuri; (F) Malahlapanga. 


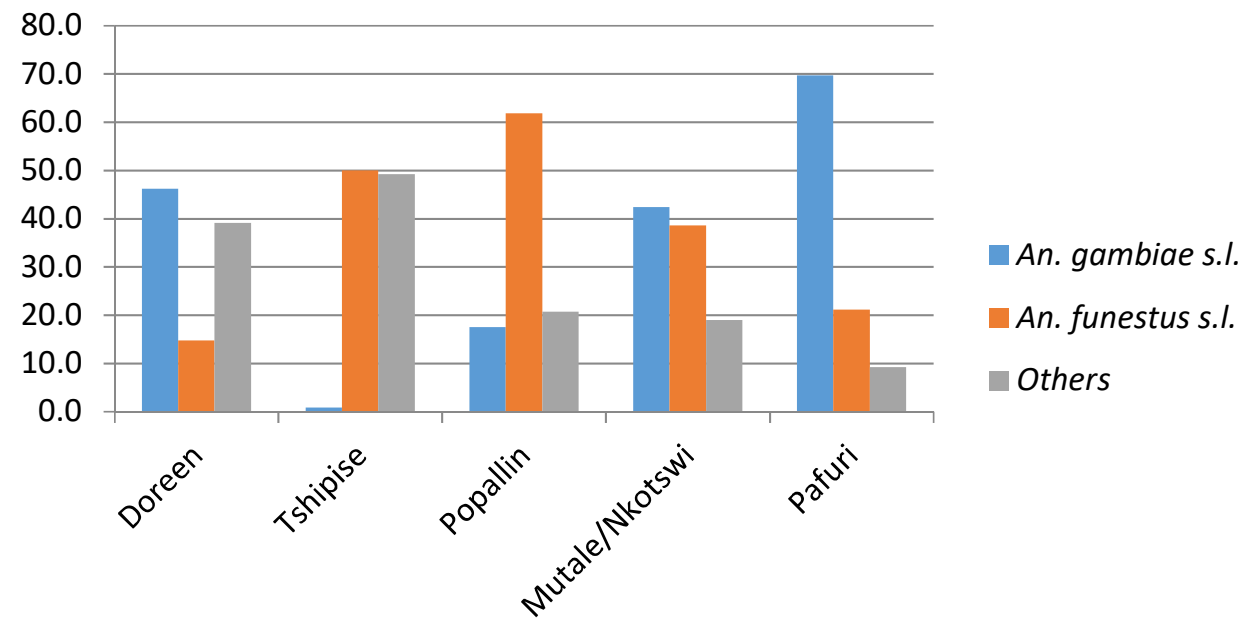

Figure 6. Percentage of Anopheles funestus group and An. gambiae complex collected in Limpopo Province in 2017/18.

\subsection{Sporozoite Assays}

A sample of 369 anopheline mosquitoes were tested using a Plasmodium sporozoite multiplex PCR assay [22]. Samples included 125 An. rivulorum, 18 An. rivulorum-like, 46 An. vaneedeni, 13 An. leesoni, 82 An. quadriannulatus, seven An. merus, three An. arabiensis and 75 specimens of various Anopheles species. All were negative. This lack of finding sporozoites may simply reflect inadequate sample sizes for some of the vector species.

\section{Discussion}

The epidemiological picture has changed dramatically in the malaria-endemic regions of South Africa, from the historic setting of the early 20th century when it became known that Anopheles mosquitoes were the main agents of transmission, to the present. Poverty continues to remain widespread in rural areas and large numbers of people still live in sub-optimal housing offering inadequate protection against entry by mosquitoes. A lack of electricity with inability to afford propane gas necessitates outdoor cooking with charcoal or wood, and inadequate ventilation drives people outdoors to cool down in the evening hours. However, almost a century of State-implemented vector control has resulted in a shift in malaria parasite transmission dynamics. South Africans were global pioneers in testing and implementing indoor house spraying against what were the two primary vectors, An. gambiae and An. funestus, in the first half of the 20th century, demonstrating in the early 1930s that indoor spraying resulted in dramatic reduction of mosquitoes and malaria [8,41,42]. This led to the adoption in South Africa (and very soon also multiple other countries in the world) of house spraying as a key component of a formalized vector control strategy, at first using a 1:18 mixture of pyrethrum/paraffin $[41,42]$ for spraying on walls but changing to dichlorodiphenyltrichloroethane (DDT) in 1946, the latter remaining the primary vector control intervention in South Africa until 1996, when pyrethroids were added due to public concern about DDT toxicity $[3,4,43,44]$. While this led to the disappearance of An. gambiae s.s. and An. funestus from the country, the potential for very rapid re-invasion and resurgence from neighboring countries was amply demonstrated in the late 1990s when, unfortunately, An. funestus in southern Mozambique had developed insecticide resistance to pyrethroids [45]. When DDT was removed, this vector came back into South Africa causing a major malaria epidemic [3,4]. It is widely believed that as a consequence of IRS suppressing the major indoor-resting vectors, the outdoor-biting An. arabiensis has for a long time been the primary vector of malaria in large parts of South Africa [46-49]. This conviction is likely to hold true in KwaZulu-Natal where An. arabiensis is common and known to harbour Plasmodium parasites [49], but some scepticism 
may be appropriate for the more northern areas of South Africa where the species is consistently recorded at very low levels $[19,26]$.

\subsection{Vector Status of Members of the Anopheles Gambiae Complex and Their Role in the Limpopo River Valley}

In KwaZulu-Natal Province, An. arabiensis is common and has recently been implicated in malaria transmission [49], but various studies suggest that it is a rare species further north, especially in Limpopo Province [19,26], including our own findings during the 2017-2018 survey of the Limpopo River Valley. Two other members of the An. gambiae complex occur widely in the warm, lowland regions of north-eastern South Africa where malaria remains endemic. Anopheles quadriannulatus is known to host $P$. falciparum in laboratory studies [50] but has thus far never been incriminated as a vector in nature. This species has an interesting and apparently fluctuating presence across its area of distribution in South Africa, known to be abundant in Limpopo and Mpumalanga Provinces [15] but more uncommon in KwaZulu-Natal. It's presence at Malahlapanga in northern Kruger National Park has raised considerable interest in what drives population abundance in a setting that offers apparently perfect breeding conditions year-round. In this particular wildlife setting An. arabiensis maintained complete dominance for several decades to the near total exclusion of An. quadriannulatus [16,24,26] but the situation was inexplicably reversed sometime around 2012 (Braack, Munhenga, personal observations), with An. quadriannulatus dominating the Anopheles community despite no detectable difference in breeding site availability, water composition or quality, or wildlife host composition or abundance. Our October 2018 sampling (Table 10) suggests that An. arabiensis has re-established its previous dominance at the site. Such shifts highlight our poor understanding of the factors affecting population distribution and abundance. However, An. quadriannulatus only reluctantly feeds on humans so that despite its known ability to host $P$. falciparum it is unlikely to be a significant factor in overall malaria epidemiology. Our survey in the Limpopo River Valley showed that An. quadriannulatus is common in inhabited rural areas but An. arabiensis is rare (aside from Pafuri and Malahlapanga in the wildlife conservation area of the Kruger National Park with few people at these sites). It is difficult to reconcile the generally accepted non-vector status of An. quadriannulatus and the scarcity of An. arabiensis with the rather high seasonal transmission of malaria that occurs in this northern region of South Africa, which suggests other vectors play a more important role.

Anopheles merus, a saltwater-breeding member of the An. gambiae complex, is widely distributed across the malaria-endemic provinces of South Africa, generally at low levels except in specific areas where it becomes locally abundant. This species too displays apparent adaptive plasticity, being able to shift from its more usual association with brackish-water breeding sites $[38,51]$ in coastal areas, to exploit both saltwater and freshwater environments much further inland, such as in South Africa [25]. Anopheles merus is broadly distributed in the eastern and south-eastern regions of sub-Saharan Africa and adjacent Indian Ocean islands [52] and is an important vector of malaria in many areas where it occurs $[51,53,54]$. However, its very low presence in the malaria-afflicted regions of the Limpopo River Valley, as reflected in our survey results summarized in Table 10, suggest that it is not an important contributor to malaria transmission in this area.

The single specimen of An. gambiae s.s. collected in February 2018 at Popallin Ranch on the Zimbabwe border requires further investigation. Earlier records show the presence of this species at Sibasa, Thohoyandou, Limpopo Province in 1974 [39] and Pelindaba, northern KwaZulu-Natal Province in 1977 [40], as well as neighbouring Zimbabwe [23] and Mozambique [33].

\subsection{Vector Status of Members of the Anopheles Funestus Group and Their Role in the Limpopo River Valley}

Various members of the An. funestus group have been recorded in Limpopo Province [14,19,43]. Apart from An. funestus, all other species in the group have been regarded as non-vectors until recently when Burke et al. [55] confirmed the presence of $P$. falciparum sporozoites in An. vaneedeni in Mpumalanga and KwaZulu-Natal Provinces. Four species, An. leesoni, An. parensis, An. rivulorum and An. rivulorum-like, were recorded from Shingwedzi in the Kruger National Park in 2015 [17,56]. 
In this current paper we report a high abundance of An. rivulorum in the Vhembe District of Limpopo Province, together with several other members of the An. funestus group (Table 10). Of these, An. rivulorum, An. leesoni, An. parensis and An. vaneedeni are known to host P. falciparum [48,55,57-59], thus demonstrating the potential of these species as vectors in residual malaria settings. We suggest that given the known ability of members of the An. funestus group to host $P$. falciparum, these species should be considered as likely to be significant vectors of malaria in this region. Even if only a small proportion of specimens are infected, their collective contribution would make them significant.

Based on human landing catches in Limpopo Province, La Grange and Coetzee [14] reported An. funestus group females as being most active in the first two hours after sunset, which together with the known status of anthropophagy, exophagy and sporozoite positivity [59], predisposes at least some of these species as potential outdoor secondary vectors. Furthermore, these species are not influenced to any great extent by rainfall [8], relying on year-round breeding sites in the Mutale (Bende Mutale), Nwanedi (Popallin Ranch) and Nzelele (Doreen Farms and Tshipise) rivers.

Anopheles funestus was historically a major vector of malaria in South Africa and continues to play a major role in malaria transmission in neighboring Mozambique and Zimbabwe. The threat of re-invasion by this species from neighboring countries cannot be ignored as evidenced by the very rapid and massive malaria resurgence following insecticide failure in KwaZulu-Natal Province in the late 1990's [3,4]. Our surveys in 2017-2018, which yielded a solitary An. funestus female at Popallin Ranch close to the Zimbabwe border, suggests that any let-up in the annual indoor spraying programme may also create an opportunity for this species, as well as An. gambiae s.s., to re-enter and establish a foothold in Limpopo.

\subsection{Other Anophelines of Potential Vector Importance}

During the initial years (or decades) of malaria vector control, it was resource-efficient to focus efforts on the known and most abundant vector species, which accounted for the overwhelming preponderance of transmission. However, as the target of malaria elimination approaches and residual malaria is confronted despite ongoing "traditional" vector control applications, it becomes important to consider the possible contribution of other mosquito species which could account for persistent low-incidence transmission, especially by species that feed outdoors and use cattle and other animals as additional blood-meal sources. Such "secondary" vectors may in fact then become the new "primary" vectors, and many such species have been incriminated in Africa [38].

Swellengrebel et al. [2] in 1931 reported parasite-infected An. pretoriensis in widely separate locations in South Africa. Anopheles rufipes, An. coustani and An. squamosus have all been found to host P. falciparum sporozoites elsewhere in Africa [38] and all these species were present in our surveys in the Limpopo River Valley, often commonly as with An. rufipes and An. pretoriensis (Figure 4).

The recent findings of $P$. falciparum infected An. parensis [48] and An. vaneedeni [55] in Mpumalanga and Kwazulu/Natal Provinces, require urgent investigations into the distribution of these species, their biology and their roles in transmission in other areas of the region. As the malaria elimination target is approached, more, not less, entomological investigations are needed to support the implementation of novel vector control strategies that will be required in order to reach the goal of elimination.

\subsection{Importation of Infective Mosquitoes into South Africa}

A proportion of local malaria cases in Limpopo Province are likely to have been caused by the importation of infective mosquitoes into South Africa from neighboring highly endemic regions, especially Mozambique. This phenomenon is known as odyssean malaria and is akin to the phenomenon of airport malaria except that it is postulated that most of the infective mosquitoes are inadvertently transported considerable distances by land. A system of migrant labour for the many gold and other mines, especially but not exclusively in Gauteng Province, depends on many thousands of Mozambicans and Zimbabweans coming in large measure from malaria high-burden rural areas in their respective countries. These people return home each year for annual vacation with their families 
and depend on bus transport. Such vehicles provide refuge for mosquitoes during overnight stops in those countries and bring infected Anopheles back into South Africa. A proxy for the frequency of such importation comes from the non-endemic Gauteng Province, in which 5-20 odyssean malaria cases are reported annually [60]. As it is not currently possible to distinguish between local and odyssean malaria in Limpopo Province, the actual frequency of this occurrence is unknown, but is a likely contributor to malaria epidemiology in all of South Africa's malaria affected provinces.

\section{Conclusions}

A literature survey supports our field survey findings that Anopheles arabiensis is a rare species in the malaria-endemic Limpopo River Valley of Vhembe region, Limpopo Province, except for locations within the Kruger National Park wildlife preserve. This does not reflect sampling inadequacy, as the methods used were capable of detecting An. arabiensis in situations where it does occur, as in the Kruger National Park, by way of larval sampling, human landing catches and $\mathrm{CO}_{2}$-baited net or light traps.

Anopheline mosquitoes are not distributed homogeneously across the landscape either in space or time but vary in community composition/species richness in ways that are rarely easy to explain. Their abundance also varies across sites and over time again in ways that are not always predictable.

It is difficult to correlate patterns of malaria case incidence with presence and especially abundance of An. arabiensis, the species which is widely held to be the prime malaria vector in the drier inland savanna regions of southern Africa. It may be that other anopheline species are playing an as yet unrecognized role in malaria transmission, in particular members of the An. funestus group which are widespread and abundant in the region, but also other species such as An. pretoriensis and An. rufipes.

It should be recognized that known, highly effective vectors such as An. funestus and An. gambiae s.s., remain prevalent in areas adjoining South Africa and the available evidence suggests that these species are kept at bay only because of continued widespread vector control interventions, in particular IRS. Although only one An. funestus and one An. gambiae s.s. were collected during our survey in the Limpopo River Valley, it demonstrates the potential for these species to re-colonize Limpopo Province if control efforts are reduced.

A small proportion of local malaria cases recorded in Limpopo Province are likely caused by the inadvertent importation of infective mosquitoes from neighbouring endemic regions.

Given that the available evidence suggests An. arabiensis is almost certainly not playing a significant role in malaria transmission in the Vhembe District, we propose that additional research effort, with greater and more frequent sampling intensity over a longer period, should be directed towards establishing which species are serving as vectors, so that appropriate control measures can be targeted at such species.

Author Contributions: L.B. conceptualized and wrote the initial draft, with subsequent additions and editorial comments by authors as listed. Authors were substantially involved in collection of literature (L.B., M.C., B.B.), obtaining Ethics approvals (R.B., T.K.), facilitating logistics (R.B., T.K.), assays of specimens (Y.D.-M., A.G., M.K., S.-V.O., Y.L., D.E.N., A.J.C.), analysing and interpretation of results (all authors), read and approved the final manuscript (all authors). All authors have read and agreed to the published version of the manuscript.

Funding: Funding for the field visits was provided by the UP Institute for Sustainable Malaria Control and South African Medical Research Council Collaborating Centre for Malaria Research. The NICD in Johannesburg provided materials for PCR and ELISA assays. MC is funded by a South African National Research Foundation grant \#113300.

Acknowledgments: We thank SANParks for logistical support enabling field collections in Kruger National Park, in particular Danny Govender, Sharon Thompson and Herman Ntimane. We thank Mike Mabunda and George Makhuvele, Entomology staff of the Limpopo Malaria Control Programme, who provided field support on one occasion, and Programme Manager Eric Mabunda for general support. Megan Riddin and Milehna Guarido of the UP Centre for Viral Zoonoses and Cyril Ndonyane of the UP ISMC assisted with fieldwork on specific occasions. Takalani Makhantisa (UP ISMC) provided PCR laboratory support.

Conflicts of Interest: The authors declare no conflicts of interest.

Availability of Data and Materials: The data supporting the conclusions of this article are included within the article. Enquiries for more detailed data should be directed to the Corresponding Author. 


\section{Abbreviations}

$\begin{array}{ll}\text { CDC } & \text { Centres for Disease Control and Prevention } \\ \text { DDT } & \text { Dichlorodiphenyltrichloroethane } \\ \text { IRS } & \text { Indoor Residual Spraying (of insecticides inside houses) } \\ \text { KNP } & \text { Kruger National Park } \\ \text { NDoH } & \text { National Department of Health } \\ \text { NICD } & \text { National Institute for Communicable Diseases } \\ \text { PCR } & \text { Polymerase Chain Reaction } \\ \text { s.l. } & \text { sensu lato (in the broad sense, i.e., the group or complex) } \\ \text { s.s. } & \text { sensu stricto (in the strict sense, i.e., the original species) } \\ \text { UP ISMC } & \text { University of Pretoria Institute for Sustainable Malaria Control }\end{array}$

\section{References}

1. Bulpin, T.V. Lost Trails of the Transvaal; Books of Africa Party publisher: Cape Town, South Africa, 1983.

2. Swellengrebel, N.H.; Annecke, S.; De Meillon, B. Malaria investigations in some parts of the Transvaal and Zululand. Publ S. Afr. Inst. Med. Res. 1931, 4, 245-274.

3. Mabaso, M.L.; Sharp, B.; Lengeler, C. Historical review of malarial control in southern African with emphasis on the use of indoor residual house-spraying. Trop. Med. Int. Health 2004, 9, 846-856. [CrossRef] [PubMed]

4. Coetzee, M.; Kruger, P.; Hunt, R.; Durrheim, D.; Urbach, J.; Hansford, C. Malaria in South Africa: 110 years of learning to control the disease. S. Afr. Med. J. 2013, 103, 770-778. [CrossRef] [PubMed]

5. Cox, F.E. History of the discovery of the malaria parasites and their vectors. Parasit. Vectors 2010, $3,5$. [CrossRef] [PubMed]

6. Ingram, A.; De Meillon, B. A mosquito survey of certain parts of South Africa, with special reference to the carriers of malaria and their control. Part, I. Publ. S. Afr. Inst. Med. Res. 1927, 22, 1-81.

7. Ingram, A.; De Meillon, B. A mosquito survey of certain parts of South Africa, with special reference to the carriers of malaria and their control. Part II. Publ. S. Afr. Inst. Med. Res. 1929, 4, 83-170.

8. De Meillon, B. Entomological studies-Observations on Anopheles funestus and Anopheles gambiae in the Transvaal. Publ. S. Afr. Inst. Med. Res. 1934, 32, 195-248.

9. Paterson, H.E. Direct evidence for the specific distinctness of forms A, B and C of the Anopheles gambiae complex. Riv. Malariol. 1964, 43, 191-196.

10. Paterson, H.E.; Paterson, J.S.; Van Eeden, G.J. A new member of the Anopheles gambiae complex: A preliminary report. Med. Proc. 1963, 9, 414-418.

11. Davidson, G.; Paterson, H.E.; Coluzzi, M.; Mason, G.F.; Micks, D.W. The Anopheles gambiae complex. In Genetics of Insect Vectors of Disease; Wright, J.W., Pal, R., Eds.; Elsevier: Amsterdam, The Netherlands, 1972; pp. 211-250.

12. Coluzzi, M.; Sabatini, A.; Petrarca, V.; Di Deco, M.A. Chromosomal differentiation and adaptation to human environments in the Anopheles gambiae complex. Trans. R. Soc. Trop. Med. Hyg. 1979, 73, 483-497. [CrossRef]

13. Steyn, J.J.; Rose Innes, R.; Schulz, K.H. A culicine mosquito survey of the upper Limpopo River Valley. J. Entomol. Soc. S. Afr. 1955, 18, 238-246.

14. La Grange, J.; Coetzee, M. A mosquito survey of Thomo village, Northern Province, South Africa, with special reference to the bionomics of exophilic members of the Anopheles funestus group (Diptera: Culicidae). Afr. Entomol. 1997, 5, 295-299.

15. Govere, J.; Durrheim, D.N.; Coetzee, M.; Hunt, R.H.; La Grange, J.J. Captures of mosquitoes of the Anopheles gambiae complex (Diptera: Culicidae) in the Lowveld Region of Mpumalanga Province, South Africa. Afr. Entomol. 2000, 8, 91-99.

16. Munhenga, G.; Brooke, B.D.; Spillings, B.; Essop, L.; Hunt, R.H.; Midzi, S.; Govender, D.; Braack, L.; Koekemoer, L.L. Field study site selection, species abundance and monthly distribution of anopheline mosquitoes in the northern Kruger National Park, South Africa. Malar. J. 2014, 13, 27. [CrossRef] [PubMed]

17. Cornel, A.J.; Lee, Y.; Almeida, A.P.G.; Johnson, T.; Mouatcho, J.; Venter, M.; De Jager, C.; Braack, L. Mosquito community composition in South Africa and some neighboring countries. Parasit. Vectors 2018, 11, 331. [CrossRef] [PubMed] 
18. Brisco, K.K.; Cornel, A.J.; Lee, Y.; Mouatcho, J.; Braack, L. Comparing efficacy of a sweep net and a dip method for collection of mosquito larvae in large bodies of water in South Africa. F1000Research 2016, 5, 713. [CrossRef] [PubMed]

19. Gillies, M.T.; Coetzee, M. A supplement to the Anophelinae of Africa south of the Sahara (Afrotropical Region). Publ. S. Afr. Inst. Med. Res. 1987, 55, 1-143.

20. Koekemoer, L.L.; Kamau, L.; Hunt, R.H.; Coetzee, M. A cocktail polymerase chain reaction (PCR) assay to identify members of the Anopheles funestus (Diptera: Culicidae) group. Am. J. Trop. Med. Hyg. 2002, 66, 804-811. [CrossRef] [PubMed]

21. Scott, J.A.; Brogdon, W.G.; Collins, F.H. Identification of single specimens of the Anopheles gambiae complex by the polymerase chain reaction. Am. J. Trop. Med. Hyg. 1993, 49, 520-529. [CrossRef] [PubMed]

22. Padley, D.; Moody, A.H.; Chiodini, P.L.; Saldanha, J. Use of a rapid, single-round, multiplex PCR to detect malarial parasites and identify the species present. Ann. Trop. Med. Parasitol. 2003, 97, 131-137. [CrossRef] [PubMed]

23. Mahon, R.J.; Green, C.A.; Hunt, R.H. Diagnostic allozymes for routine identification of adults of the Anopheles gambiae complex (Diptera, Culicidae). Bull. Entomol. Res. 1976, 66, 25-31. [CrossRef]

24. Munhenga, G.; Brooke, B.D.; Chirwa, T.F.; Hunt, R.H.; Coetzee, M.; Govender, D.; Koekemoer, L.L. Evaluating the potential of the sterile insect technique for malaria control: Relative fitness and mating compatibility between laboratory colonized and a wild population of Anopheles arabiensis from the Kruger National Park, South Africa. Parasit. Vectors 2011, 4, 208. [CrossRef] [PubMed]

25. Coetzee, M.; Hunt, R.H.; Braack, L.; Davidson, G. Distribution of mosquitoes belonging to the Anopheles gambiae complex, including malaria vectors, south of latitude $15^{\circ}$ S. S. Afr. J. Sci. 1993, 89, 227-231.

26. Braack, L.E.O.; Coetzee, M.; Hunt, R.H.; Biggs, H.; Cornel, A.; Gericke, A. Biting pattern and host-seeking behavior of Anopheles arabiensis (Diptera: Culicidae) in northeastern South Africa. J. Med. Entomol. 1994, 31, 333-339. [CrossRef] [PubMed]

27. Mbokazi, F.; Coetzee, M.; Brooke, B.; Govere, J.; Reid, A.; Owiti, P.; Kosgei, R.; Zhou, S.; Magagula, R.; Kok, G.; et al. Changing distribution and abundance of the malaria vector Anopheles merus in Mpumalanga Province, South Africa. Public Health Action 2018, 8, S39-S43. [CrossRef] [PubMed]

28. Sande, S.; Zimba, M.; Chinwada, P.; Masendu, H.; Makuwaza, A. Malaria vector species composition and relative abundance in Mutare and Mutasa districts, Zimbabwe. J. Entomol. Acarol. Res. 2015, 47, 79-85. [CrossRef]

29. Masendu, H.; Hunt, R.H.; Koekemoer, L.L.; Brooke, B.; Govere, J.; Coetzee, M. Spatial and temporal distributions and insecticide susceptibility of malaria vectors in Zimbabwe. Afr. Entomol. 2005, 13, $25-34$.

30. Mpofu, S.M. Seasonal vector density and disease incidence patterns of malaria in an area of Zimbabwe. Trans. R. Soc. Trop. Med. Hyg. 1985, 79, 169-175. [CrossRef]

31. Taylor, P.; Mutambu, S. A review of the malaria situation in Zimbabwe with special reference to the period 1972-1981. Trans. R. Soc. Trop. Med. Hyg. 1986, 80, 12-19. [CrossRef]

32. Zengenene, M.P.; Soko, W.; Brooke, B.D.; Koekemoer, L.L.; Govere, J.; Mazarire, T.T. Anopheles species composition and breeding habitat characterisation in Chiredzi District, Zimbabwe. Afr. Entomol. 2020, 28, 84-94. [CrossRef]

33. Casimiro, S.; Coleman, M.; Hemingway, J.; Sharp, B. Insecticide resistance in Anopheles arabiensis and Anopheles gambiae from Mozambique. J. Med. Entomol. 2006, 43, 276-282. [CrossRef]

34. Kyalo, D.; Amratia, P.; Mundia, C.W.; Mbogo, C.M.; Coetzee, M.; Snow, R.W. A geo-coded inventory of anophelines in the Afrotropical Region south of the Sahara: 1898-2016. Wellcome Open Res. 2017, 2, 57. [CrossRef] [PubMed]

35. Brooke, B.D.; Kloke, G.; Hunt, R.H.; Koekemoer, L.L.; Temu, E.A.; Taylor, M.E.; Small, G.; Hemingway, J.; Coetzee, M. Bioassay and biochemical analyses of insecticide resistance in southern African Anopheles funestus (Diptera: Culicidae). Bull. Entomol. Res. 2001, 91, 265-272. [CrossRef] [PubMed]

36. Casimiro, S.; Coleman, M.; Mohloai, P.; Hemingway, J.; Sharp, B. Insecticide resistance in Anopheles funestus (Diptera: Culicidae) from Mozambique. J. Med. Entomol. 2006, 43, 267-275. [CrossRef] [PubMed]

37. Casimiro, S.; Hemingway, J.; Sharp, B.; Coleman, M. Monitoring the operational impact of insecticide usage for malaria control on Anopheles funestus from Mozambique. Malar. J. 2007, 6, 142. [CrossRef] [PubMed] 
38. Gillies, M.T.; De Meillon, B. The Anophelinae of Africa south of the Sahara (Ethiopian Zoogeographical Region). Publ. S. Afr. Inst. Med. Res. 1968, 54, 1-343.

39. Smith, A.; Hansford, C.F.; Thomson, J.F. Malaria along the southernmost fringe of its distribution in Africa: Epidemiology and control. Bull. World Health Org. 1977, 55, 95-103. [PubMed]

40. Miles, S.J. Enzyme variation in the Anopheles gambiae Giles group of species (Diptera: Culicidae). Bull. Entomol. Res. 1978, 68, 85-96. [CrossRef]

41. De Meillon, B. The control of malaria in South Africa by measures directed against the adult mosquitoes in habitations. Quart Bull. Health Org. L.o N. 1936, 5, 134-137.

42. Park Ross, G.A. Insecticide as a major measure in control of malaria, being an account of the methods and organisation put in force in Natal and Zululand during the past six years. Quart Bull. Health Org. L.o N. 1936, $5,114-133$

43. Brooke, B.; Koekemoer, L.; Kruger, P.; Urbach, J.; Misiani, E.; Coetzee, M. Malaria vector control in South Africa. S. Afr. Med. J. 2013, 103, 784-788. [CrossRef] [PubMed]

44. Sharp, B.L.; Ngxongo, S.; Botha, M.J.; Ridl, F.; Le Sueur, D. An analysis of 10 years of retrospective malaria data from the KwaZulu areas of Natal. S. Afr. J. Sci. 1988, 84, 102-106.

45. Hargreaves, K.; Koekemoer, L.L.; Brooke, B.D.; Hunt, R.H.; Mthembu, J.; Coetzee, M. Anopheles funestus is resistant to pyrethroid insecticides in South Africa. Med. Vet. Entomol. 2000, 14, 181-189. [CrossRef] [PubMed]

46. Hansford, C.F. Recent trends in the control and treatment of malaria. S. Afr. Med. J. 1972, 46, 635-637.

47. Sharp, B.L.; Le Sueur, D.; Bekker, P. Effect of DDT on survival and blood feeding success of Anopheles arabiensis in northern KwaZulu, Republic of South Africa. J. Am. Mosq. Control Assoc. 1990, 6, 197-202. [PubMed]

48. Burke, A.; Dahan-Moss, Y.; Duncan, F.; Qwabe, B.; Coetzee, M.; Koekemoer, L.; Brooke, B. Anopheles parensis contributes to residual malaria transmission in South Africa. Malar. J. 2019, 18, 257. [CrossRef] [PubMed]

49. Dandalo, L.C.; Brooke, B.D.; Munhenga, G.; Lobb, L.N.; Zikhali, J.; Ngxongo, S.P.; Zikhali, P.M.; Msimang, S.; Wood, O.R.; Mofokeng, M.; et al. Population dynamics and Plasmodium falciparum (Haemosporida: Plasmodiidae) infectivity rates for the malaria vector Anopheles arabiensis (Diptera: Culicidae) at Mamfene, KwaZulu-Natal, South Africa. J. Med. Entomol. 2017, 54, 1758-1766. [CrossRef] [PubMed]

50. Takken, W.; Eling, W.; Hooghof, J.; Dekker, T.; Hunt, R.H.; Coetzee, M. Susceptibility of Anopheles quadriannulatus Theobald (Diptera: Culicidae) to Plasmodium falciparum. Trans. R. Soc. Trop. Med. Hyg. 1999, 93, 578-580. [CrossRef]

51. Sinka, M.E.; Bangs, M.J.; Manguin, S.; Coetzee, M.; Mbogo, C.M.; Hemingway, J.; Patil, A.P.; Temperley, W.H.; Gething, P.W.; Kabaria, C.W.; et al. The dominant Anopheles vectors of human malaria in Africa, Europe and the Middle East: Occurrence data, distribution maps and bionomic précis. Parasit. Vectors 2010, 3, 117. [CrossRef] [PubMed]

52. Irish, S.R.; Kyalo, D.; Snow, R.W.; Coetzee, M. Updated list of Anopheles species (Diptera: Culicidae) by country in the Afrotropical Region and associated islands. Zootaxa 2020, 4747, 401-449.

53. Temu, E.; Minjas, J.; Coetzee, M.; Hunt, R.; Shiff, C. The role of four anopheline species (Diptera: Culicidae) in malaria transmission in coastal Tanzania. Trans. R. Soc. Trop. Med. Hyg. 1998, 92, 152-158. [CrossRef]

54. Cuamba, N.; Mendis, C. The role of Anopheles merus in malaria transmission in an area of southern Mozambique. J. Vector-borne Dis. 2009, 46, 157-159. [PubMed]

55. Burke, A.; Dandalo, L.; Munhenga, G.; Dahan-Moss, Y.; Mbokazi, F.; Ngxongo, S.; Coetzee, M.; Koekemoer, L.; Brooke, B. A new malaria vector mosquito in South Africa. Sci. Rep. 2017, 7, 43779. [CrossRef] [PubMed]

56. Mouatcho, J.; Cornel, A.J.; Dahan-Moss, Y.; Koekemoer, L.L.; Coetzee, M.; Braack, L. Detection of Anopheles rivulorum-like, a member of the Anopheles funestus group, in South Africa. Malar. J. 2018, 17, 195. [CrossRef] [PubMed]

57. Temu, E.A.; Minjas, J.N.; Tuno, N.; Kawada, H.; Takagi, M. Identification of four members of the Anopheles funestus (Diptera: Culicidae) group and their role in Plasmodium falciparum transmission in Bagamoyo coastal Tanzania. Acta Trop. 2007, 102, 119-125. [CrossRef] [PubMed]

58. Wilkes, T.; Matola, Y.; Charlwood, J. Anopheles rivulorum, a vector of human malaria in Africa. Med. Vet. Entomol. 1996, 10, 108-110. [CrossRef] [PubMed] 
59. Kawada, H.; Dida, G.O.; Sonye, G.; Njenga, S.M.; Mwandawiro, C.; Minakawa, N. Reconsideration of Anopheles rivulorum as a vector of Plasmodium falciparum in western Kenya: Some evidence from biting time, blood preference, sporozoite positive rate, and pyrethroid resistance. Parasit. Vectors. 2012, 5, 230. [CrossRef] [PubMed]

60. Frean, J.; Brooke, B.; Thomas, J.; Blumberg, L. Odyssean malaria outbreaks in Gauteng Province, South Africa, 2007-2013. S. Afr. Med. J. 2014, 104, 335-338. [CrossRef] [PubMed]

(c)

(C) 2020 by the authors. Licensee MDPI, Basel, Switzerland. This article is an open access article distributed under the terms and conditions of the Creative Commons Attribution (CC BY) license (http://creativecommons.org/licenses/by/4.0/). 